\title{
INARIN EMÄNTÄKOULUSSA: C-KASETTI JOKAPAIKKAISEN KUUNTELUN EDISTÄJÄNÄ
}

190o-luku oli tallennetun ja liikkuvan musiikin vuosisata. Ensimmäistä kertaa historiassa Soitto ja laulu kyettiin irrottamaan tietystä kuunteluun tarkoitetusta paikasta ensin matkalaukkugramofonin ja sittemmin kelanauhurin ja transistoriradion avulla. Viimemainitun pieni koko, kestävyys ja helppokäyttöisyys olivat ominaisuuksia, jotka olivat myös 1960-luvulla markkinoille tuodussa c-kasetissa. Lisäksi kasetti vapautti käyttäjänsä laatimaan mieleisiään musiikkikoosteita, kuuntelemaan musiikkiesityksiä haluamassaan järjestyksessä ja niin monta kertaa kuin huvitti. Musiikkia tallentavana ja siirtävänä alustana kasetti edesauttoi osaltaan niiden käytäntöjen muodostumista, jotka ovat erottamaton osa tämän päivän musiikin yksityistä ja sosiaalista kuuntelua.

Kasetti vaikutti musiikin tuotantoon, jakamiseen ja sosiaaliseen käyttöön käytännöllisesti katsoen kaikkialla maailmassa. Tähän nähden on akateeminen kiinnostus aihetta kohtaan ollut varsin vähäistä, näin etenkin Länsi-Euroopan maissa ja Yhdysvalloissa. Merkillepantavia poikkeuksia ovat Peter Manuelin tutkimus intialaisesta kasettikulttuurista, jonka mukaan c-kasetin käyttäjät mursivat toiminnallaan levy-yhtiöiden valta-aseman ja synnyttivät paikallisia musiikin tuotannon ja levittämisen muotoja sekä Roger Wallisin ja Krister Malmin Tansaniaan, Tunisiaan, Ruotsiin ja Trinidadiin sijoittuva tutkimus, jossa tarkastellaan kasetin asemaa osana maiden musiikkiteollisuutta. Laitteen demokratisoivat vaikutuk- 
set olivat merkittäviä myös Afrikan, Lähi-idän, Etelä-Amerikan ja jälkikommunistisen Itä-Euroopan musiikkikulttuureissa. (Wallis \& Malm 1984; Manuel 1988; 1993; Katz 2004: 12-13.)

Suomessa kasettia on tarkasteltu osana ääniteteollisuuden teknologista ja sisällöllistä muutosta (Gronow \& Saunio 1990; Muikku 2001), mutta kattava kartoitus kasetin merkityksestä musiikin loppukäyttäjille on vielä tekemättä. Tähän keskitymme parhaillaan toteutettavassa, Suomen Akatemian rahoittamassa Musiquitous-hankkeessa. Osana laajempaa musiikin kuuntelukulttuurin muutosta selvitämme c-kasetin vaikutusta yksityiseen ja yhteiseen musiikinkulutukseen sekä niihin musiikinkäytön ja -tuotannon muotoihin, jotka osaltaan rakensivat nykyisiä musiikinkuuntelukäytäntöjä. Näitä ovat muiden muassa kotiäänittäminen, musiikin yhteisöllinen jakaminen sekä musiikinkulutuksen laadulliset ja määrälliset muutokset. (Kilpiö \& Uimonen 2010; Kilpiö \& Lehtinen 2011; Musiq 2012.)

Artikkelissani tarkastelen sitä, missä kasetteja käytettiin, millä tavalla ja minkä ikäisinä eri sukupolvet aloittivat kasetinkäytön sekä millainen vaikutus kasetilla oli heidän musiikinkulutukseensa. Kontekstoin tutkimusta taustoittamalla kasettien yleistymiseen vaikuttaneita tekijöitä ja saatavuutta sekä kuinka tallennetut puhe ja musiikillinen ääni tulivat kiinteäksi osaksi arkea 1970-luvulta lähtien. Empiirisenä tutkimusaineistona ovat kasetinkäyttöä koskevan internetmuistitietokeruun vastaukset, teoreettisena tarkastelunäkökulmana jokapaikkaisen musiikin käsite.

\section{Jokapaikkainen musiikki}

Jokapaikkainen ts. ubiikkimusiikki (engl. ubiquitous music) on kaikkialla läsnä olevaa musiikkia. Termi on johdettu jokapaikkaisen tietotekniikan käsitteestä (engl. ubiquitous computing), jolla tarkoitetaan kaikkialla läsnä olevaa tietotekniikkaa sekä sitä, millaisia vaikutuksia tällä on jokapäiväiseen elämäämme. (Kassabian 2002: 132; Heikkilä 2007.)

Käsitteitä voidaan selkeyttää rinnastamalla ne ubiikkiutta edeltäviin kulttuurihistoriallisiin muutoksiin, kuten käsikirjoitettujen ja painettujen tekstien sekä lukutaidon yleistymiseen. Aluksi tekstejä säilytettiin keskitetysti luostareissa ja kirjastoissa, minkä jälkeen kirjoitettu informaatio yleistyi yksityiskokoelmien 
kirjoina ja muina painotuotteina. Viimein painetusta tekstistä tuli osa ihmisten jokapäiväistä elämää. (Kassabian 2002: 132.)

Myös musiikin tallentamiseen, välittämiseen ja kuunteluun liittyvät käytännöt ovat muuttuvia. Musiikillisen informaation muistiin merkitsemistä ja toistamista varten kehitettiin ensin nuottikirjoitus, sittemmin ääntä taltioivat alustat, joille musiikki kiinnitettiin aluksi mekaanisesti, sen jälkeen sähkömekaanisesti ja viimein digitaalisesti. Tätä 190o-luvulla musiikin käyttötapoja perusteellisesti ja peruuttamattomasti muokannutta äänen tallennettavuutta, kopioitavuutta ja siirrettävyyttä kutsutaan transfoniaksi (Uimonen 2005: 61).

Tekstien ja musiikin käyttökontekstien räjähdysmäinen lisääntyminen määritti ja määrittää edelleen kummankin vastaanottoa ja käyttötarkoitusta. Maitopurkin tuoteselosteesta ei haeta esteettistä nautintoa samalla tavalla kuin runosta, vaikka molempien lukemisessa on kyse tekstin tulkinnasta eikä matkapuhelimen soittoääni ole tarkoitettu keskittyneesti, kontemplatiivisesti kuunneltavaksi sävelteokseksi, vaikka kummassakin on kyse musiikillisen äänen tulkinnasta.

Kuuntelutapojen, musiikin käyttöyhteyksien ja eri repertuaarien suhdetta toisiinsa voidaan selkeyttää jokapaikkaisen kuuntelemisen (engl. ubiquitous listening) käsitteellä. Aiheesta kirjoittanut musiikintutkija Anahid Kassabian (2002: 133) yhdistää musiikin käytön genrenormatiivisiin kuuntelutapoihin. Tällä hän viittaa siihen, kuinka kuuntelutavat, kuuntelutilanteet ja musiikkityylit tuottavat toinen toisiaan. Samoin eri musiikkityyleistä osana laajempaa äänimaiseman rakentumista kirjoittanut musiikkitieteilijä Ola Stockfelt kirjoittaa, kuinka yhden ja saman musiikkiteoksen on mahdollista liittyä erilaisiin käyttöyhteyksiin. Kuuntelijalla on käytettävissään erilaisia kuuntelutapoja, jotka muuntuvat tilanteen ja tarkoituksen mukaan. Musiikkiesitys konserttisalissa sulkee muun maailman ulkopuolelleen, kahvilassa kuultuna se rauhoittaa kuulijaa häiritseviksi koetuilta ympäristön ääniltä. (Stockfelt 1997: 132-137; Uimonen 2005: 68.)

Suuri ellei suurin osa päivittäin kuulemastamme musiikista on tarkoitettu muuten kuin tarkkaavaisesti kuunneltavaksi. Usein se on myös muiden kuin itsemme valitsemaa. Tämänkaltainen musiikin kuuntelu ja sen kuuleminen asettaa haasteita paitsi musiikintutkimukselle, myös sille kuinka itse kuuntelutapahtumaa tulisi tutkimuksellisesti tarkastella. Kassabian (2002: 131-135) kysyykin, että mikäli kontemplatiivinen kuuntelu on tuottanut länsimaisen klassisen musiikin kaanonin, eivätkö muut kuuntelutavat tuota ja uusinna muunlaisia repertuaareja. 
Vastaus on myönteinen, kun tarkastellaan esimerkiksi kaupallisten radioiden musiikkisisältöjä. Niiden päivätarjonnan tulee olla häiritsemätöntä, mutta kuitenkin riittävän mielenkiintoista sopiakseen taustoittamaan työtehtäviä ja antamaan virikettä päivän toimille. Mikäli radiokanava ei kykene näitä kriteereitä täyttämään, valitsevat kuuntelijat toisen aseman. Tätä välttääkseen kanavat ja kanavaketjut hyväksyttävät soittamansa musiikin kuuntelijoillaan erityyppisissä kuuntelutesteissä, minkä jälkeen ne valitsevat repertuaariinsa esitykset, jotka vastaavat mahdollisimman tarkasti radion kohderyhmän musiikkimakua. (Uimonen 2011: 23.)

Musiikkirepertuaareja uudistavat myös musiikin erityyppiset sosiaaliset käytöt käytöt, mikä heijastuu paikoin myös musiikinkuuntelun teknisiin laatukriteereihin. Tällöin laadullisesti hyvä äänentoisto ja siihen useasti liittyvä kontemplatiivinen kuunteleminen ovat toisarvoisia seikkoja verrattuna mielihyvään, jonka musiikin yhteinen kuuntelukokemus saa aikaan. Tästä viimeaikaisena esimerkkinä on eräs gramofonin, transistoriradion ja kasetin sosiaalisen käytön synnyttämistä jokapaikkaisen kuuntelun nykyvastineista, jota kutsutaan nimellä sodcasting. Sanassa yhdistyvät englanninkielen epämiellyttävää henkilöä tai asiaa merkitsevä sod-substantiivi ja äänitiedostojen julkaisemista internetissä tarkoittavan podcasting. Sodcastingilla tarkoitetaan matkapuhelimen kaiuttimesta soitettua musiikkia, jota nuoret soittavat julkisissa liikennevälineissä ja näin tehden ärsyttävät kanssamatkustajiaan (Hancox 2010). ${ }^{1}$ Termin takana ovat tuohtuneet kanssamatkustajat, musiikinkuuntelutapahtuman ulkopuoliset henkilöt, jotka ovat pakotettuja käyttämään samaa tilaa yhdessä musiikistaan nauttivan nuorisoryhmän kanssa.

Myös kasetissa kiinnitettiin aluksi huomiota siihen, että äänen laatu oli vinyylilevyn ääntä huonompi. Vakavammin musiikkiharrastukseensa suhtautuvat musiikinkuluttajat vieroksuivat ensi alkuun uutta formaattia, Suosikki-nuortenlehdessä julkaistun Tekniikan Maailman mainoksen sanoin "poppareiden leluna" (S 1971). Pian kuitenkin kävi selväksi, että puutteellisen äänenlaadun korvasivat kasetin mainitut ominaisuudet, joita olivat musiikin liikuteltavuus, kopioitavuus,

I "Sodcast [noun]: Music, on a crowded bus, coming from the speaker on a mobile phone. Sodcasters are terrified of not being noticed, so they spray their audio wee around the place like tomcats." (Hancox 2010.) 
tallennettavuus sekä toistovälineen kestävyys ja helppokäyttöisyys. (Kilpiö \& Uimonen 2010.)

\section{Kasetin yleistymisen edellytykset}

Musiikkikulttuurien muutoksia edesauttavat tai rajoittavat tekniset innovaatiot, niiden yleistyminen sekä taloudelliset ja lainsäädännölliset tekijät, jotka joko edesauttavat tai rajoittavat innovaatioiden käyttöönottoa. Suomessa kasettinauhureiden ja kasettien sosiaalisia ja kulttuurisia käyttötapoja ovat muovanneet muiden muassa kasettien ja kasettinauhureiden vähittäismyynti- ja postimyyntiverkoston kasvu, kotiäänittämisen yleistyminen, radioiden musiikkikäytännöt ja muutokset radioiden toimilupapolitiikassa. (Kilpiö \& Uimonen 2010.)

Kasettinauhureiden yleistyminen oli huomattavan nopeaa. Kun 1970-luvun alussa kasettisoitin oli hankittu joka kymmenenteen talouteen, oli kymmenen vuotta myöhemmin soittimien määrä kotitalouksissa 145 prosenttia. Levysoittimia oli 1970-luvun alussa 40 prosentilla talouksista, mihin vaikutti 1960-luvulle saakka jatkunut levysoittimien suojatullimaksu. Uusien laitteiden ja äänitteiden ostajat valitsivat useasti kasetin levyn sijaan. (Muikku 2001: 167.) Autoradioiden ja autokasettisoittimien myötä musiikin mobiilius lisääntyi entisestään, mitä lisäsi vielä korvalappustereoiden yleistyminen 1980-luvulla. Kun vuonna 1982 kasettisoittimia ja korvalappustereoita myytiin 30 ooo kappaletta, oli määrä kolme vuotta myöhemmin 200 ooo. (Joukkoviestimet 1998: 189; Kilpiö \& Uimonen 2010.)

Simon Frithin (1986: 272-274) mukaan teknologiset muutokset määrittävät populaarimusiikin tuotantoportaan ja artistien välisiä valtasuhteita uusiksi. Kasetin kohdalla muutos ulottui myös faneihin, sillä heille tuli mahdolliseksi koota musiikkia levyiltä ja radiosta mieleiseksi kokoelmaksi ja kuljettaa musiikkia mukanaan. Samalla kun kasetti vapautti artistin tai omakustannejulkaisujen tekijät levy-yhtiöiden tuotantokoneistosta, vapautti se myös kuuntelevan yleisön äänilevy-yhtiöiden ja Yleisradion rakentamasta populaarimusiikin kaanonista ja repertuaareista. Kokoelmakasetin tekijä suunnitteli ja toteutti tallenteen itselleen sekä yhden tai useamman henkilön yleisölle. Samalla hänen ennalta määritelty asemansa musiikkia vastaanottavana kuluttajana vaihtui aktiivisen musiikin 
käyttäjän rooliin: hän muokkasi käsillä olevasta materiaalista haluamansa kosteen haluamalleen kohderyhmälle. (Kilpiö \& Lehtinen 2011: 35.)

Näitä kasetin tasa-arvoistavia ja sen musiikin kuuntelua monipuolistaneita vaikutuksia korostettiin useissa Kasettimuistot-aineiston vastauksissa. Vuonna 1962 syntynyt nainen Pohjois-Pohjanmaalta muisteli kasettien käyttöä seuraavasti: "C-kasetit olivat minun aikani paras keksintö, se avarsi elämääni tuppukylästä koko maailmaan". Musiikinkuuntelu demokratisoituikin erityisesti tyhjien kasettien edullisen hinnan ansiosta, sillä levy-yhtiöiden uutuusjulkaisuina musiikkikasetit ja levyt olivat samanhintaisia - kasetit jopa hintavampia. Esimerkiksi tamperelaisen postimyyntiliikkeen Epe's Music Shopin syksyn 1974 luettelossa lp maksoi 26 ja kasetti 28 markkaa (23, 6 e ja 25, 4 e). (Kper 2010: Km / 748; S 1974a: 24; TK 2012.)

Myyntipisteiden lisääntyminen oli elintärkeää kasetin ja kasettisoittimien yleistymiselle ja saatavuudelle. Äänitteitä hankittiin erikoisliikkeiden ohella tavaratalojen ja markettien myyntitelineistä ja myyntipisteistä. Kioskiasetus määritteli kasetin autotuotteeksi, mikä helpotti musiikin huoltoasemahankintoja. Merkillepantavaa on, että kun 1970-luvun alussa erikoisliikkeet myivät yhdeksän kymmenestä äänitteestä, kaupattiin vuosikymmenen puolessa välissä lähes puolet vähittäiskaupan äänitteistä telineistä ja postimyynnissä. Suhde erikoisliikkeiden (50 \%), telinemyynnin (35\%) ja postimyynnin ( $15 \%$ ) välillä pysyi kutakuinkin samana 1990-luvulle saakka. (Muikku 2001: 168-169.)

Kasettien ostopaikat eivät olleet toisiaan poissulkevia. Vaikka kasettimuistokyselyn mukaan nauhoja hankittiin ylivoimaisesti eniten päivittäistavaraliikkeistä ja musiikkiliikkeistä, ostettiin niitä myös kodinkone- ja elektroniikkaliikkeistä, postimyyntiyrityksistä, kuten Fazerin musiikkikerhosta ja Epe's Music Shopista, tavarataloista kuten Anttilasta, Valintatalosta ja Stockmannilta sekä antikvariaateista, kirpputoreilta ja kierrätyskeskuksista. (Km 2010.) Merkillepantava yksityiskohta musiikinkulutuksen muutoksessa on, että lisääntyneiden ostomahdollisuuksien myötä musiikkikaseteista tuli selkeästi päivittäiseen käyttöön tarkoitettu ja muiden päivittäistuotteiden ohella hankittava hyödyke. Äänilevyn ja etenkin gramofonilevyn ostaminen erikoisliikkeistä oli kestokulutushyödykkeen hankintaa, kun taas musiikkikasetti oli vaivaton poimia ostoskoriin muiden päivittäistavaroiden ohella. 
Kasetti yleistyi myös siksi, että se oli edullinen formaatti julkaisijalleen. Kasetin monistaminen oli vaivattomampaa ja kustannustehokkaampaa äänilevyihin verrattuna, joiden valmistaminen vaati suhteellisen suuria määriä tullakseen kannattavaksi. 1970-luvun Suomessa oli vaatimattomillakin laitteilla mahdollista tuottaa markkinoille 500 kasettia päivässä. Lisäksi levy-yhtiöt pystyivät hyödyntämään back-katalogiaan (vanhaa levytuotantoa sisältävä kokoelma) edullisesti ja käyttömukavassa muodossa. Tämä johti kokoelmalevyjen ja kasettien julkaisemiseen, jotka oli koottu jonkin teeman tai yksittäisen artistin tuotannon perusteella. (Muikku 2001: 168-169.) Jo nimensäkin puolesta huoltoasemien telinemyyntiin tarkoitettuja olivat Scandian 1979 julkaiseman Autokansan kasetteja -sarjan Tutkapartio, Usvaa putkeen, Takapenkillä, Tien kuninkaita, Antaa soittaa, Vaihdetaan vapaalle ja Yön kulkija -kokoelmat (Ak 1979).

Millaista kasettimusiikkitarjonta sitten oli kuluttajan näkökulmasta tarkasteltuna? Suomalaisen pikkukaupungin musiikkikasettien ja muiden äänitteiden saatavuuden kiteyttää osuvasti vuonna 1993 tehty tapaustutkimus Virroilta. Varsinaisia ääniteliikkeitä paikkakunnalla ei ollut, mikä johtui osin läheisen Tampereen musiikkitallennetarjonnasta. Äänitteitä myytiin kahdessatoista liikkeessä, pääasiassa marketeissa, kodinkoneliikkeissä, huoltoasemilla ja postimyynnissä. Eniten äänitteitä myi S-Market Pippuri. Keskimäärin 150 äänitteen kuukausimyynti koostui käytännöllisesti katsoen kokonaan musiikki- ja äänittämättömistä kaseteista. CD-levyjä myytiin muutamia kappaleita. Äänitteet valitsi ja toimitti Fazerin levypisteen edustaja. Mikäli tuotteella ei ollut menekkiä tai kauppa päätti hankkia suuremman erän runsaasti myyviä levyjä, oli edustajan mahdollista myydä tuotteitaan vähittäiskauppiaalle listahintaa edullisemmin. (Lounela 1995: 101-102.)

Kodinkoneliikkeet myivät hittiäänitteitä joitakin kymmeniä kappaleita lähinnä nuorille kuluttajille. Huoltoasemien "matkamusiikkia" myytiin parhaimmillaan muutamia kymmeniä kappaleita kuukaudessa. Epe's Music Shopin ja etenkin Fazerin musiikkikerhon postimyynnillä oli alueen äänitemyyntiin huomattava vaikutus. Viimemainittu myi Virtojen 205 aktiivijäsenille kuukaudessa saman verran äänitteitä kuin S-Market Pippuri. (Lounela 1995: 104-105.) 


\section{Kasetti kotona ja kylässä}

Edulliset kasettinauhurit muuttivat kodin äänimaiseman ja visuaalisen ilmeen. Olohuoneen puukuoriset radiovastaanottimet ja radiogramofonit vaihtuivat 1960-luvulla televisioon, josta tuli kodin uusi viihdekeskus. Keittiöihin hankittiin pienikokoisia transistoriradioita ja radiokasettisoittimia. (Gronow \& Saunio 1990: 471-472.) Nuorisolle tuli mahdolliseksi vetäytyä omiin huoneisiinsa edullisen radionauhurinsa kanssa kuuntelemaan mieleistään musiikkia ja kuljettaa laitetta mukanaan minne mieli teki.

Transistorien ja valmiiden virtapiirien yleistyminen pudotti kodinelektroniikan valmistuskustannuksia ja samalla madalsi kodin äänentoiston hintaa. Markkinoille tuotiin laitepaketteja, jotka koostuivat kasettisoittimesta, viritinvahvistimesta, levysoittimesta ja kaiuttimista. Nämä "äänentoiston kansanautot" olivat kohtuullisen edullisia hankkia. (Gronow \& Saunio 1990: 471-472.) Kodin äänentoiston muuttuminen näkyi myös mainonnassa. Suosikki-lehdessä ilmoittaneiden Fazerin musiikkikerhon ja Hobby Hallin mainoksiin kasettisoittimet, radiokasettinauhurit ja stereo-laitepaketit ilmestyivät heti 1970-luvun alkupuolella, vuosikymmenen puolen välin jälkeen oli kooltaan suurempien Technicsin ja Pioneerin valmistamien laitteiden vuoro. Ne paransivat äänentoiston laatua ja ulkoasultaan tyylikkäinä todennäköisesti myös palauttivat musiikinkuuntelua takaisin olohuoneeseen.

Kotiäänittäjien kannalta oli suotuisaa, että Yleisradio lisäsi populaarimusiikin tarjontaa yhdessä muiden eurooppalaisten julkirahoitteisten yhtiöiden kanssa samaan aikaan, kun kasetti alkoi yleistyä. Tähän vaikuttivat valtioiden aluevesirajan ulkopuolella toimivat ns. merirosvoradiot, jotka ilman toimilupaa lähettivät lähinnä nuorille suunnattua musiikkiohjelmaa. Yleisradio reagoi kilpailuun kuuntelijoista lisäämällä populaarimusiikin osuutta lähetyksissään ja perustamalla Sävelradion keväällä 1963. Muutos oli väistämätön muuallakin, kuten Ruotsissa, jossa kanavauudistus tehtiin Suomea aiemmin. Sitä joudutti Tukholman edustalta lähetyksensä aloittanut merirosvoradio Radio Nord, jonka lähetykset kantoivat myös Suomen alueelle (ks. Kemppainen 2011).

Nuorille suunnattuun musiikkiin satsaaminen ei ollut aluksi suuren suurta. Yleisradiossa käydyt keskustelut koskivat enemmänkin rajankäyntiä kuuntelijalähtöisen ja valistavan ohjelmapolitiikan välillä, mutta kasettiakin sivuttiin. 
Pohdittiin, tulisiko Yleisradion kilpailla nuorista kuulijoista, kun nämä kuitenkin kuuntelevat omaa musiikkiaan kaseteilta. Jo tätä ennen oli radiossa havahduttu siihen, että rajoitetusta rock- ja pop-tarjonnasta huolimatta kotiäänittäminen oli alkanut. Kelanauhuria käyttävät tallentajat antoivat kipakkaa palautetta toimittajille, jos nämä sattuivat puhumaan musiikkiesitysten päälle. (Kemppainen 2011: 215-216; 221.) Kotona ärryttiin kappaleiden pilaamisesta yhtälailla senkin jälkeen, kun valtaosa äänittäjistä oli vaihtanut kelanauhat kasettinauhoihin.

Erityisesti nuorten kasetinkäyttäjien mahdollisuudet kuulla ja tallentaa haluamaansa musiikkia paranivat merkittävästi vuoteen 1985 mennessä. 1970-luvun puolen välin jälkeen Yleisradio lähetti ohjelmissaan rock- ja pop-musiikkia seitsemän tuntia viikossa, mikä lisääntyi kahteentoista viikkotuntiin Rockradion aloittamisen myötä 2.6.1980. Kaupalliset radiot aloittivat toimintansa keväällä 1985 radiotoiminnan reregulaation jälkeen ja osaltaan lisäsivät määrällisesti ja laadullisesti paikallista musiikkitarjontaa. Vaikutukset heijastuivat Yleisradionkin musiikkisisältöihin, mikä johti viimein yksinomaan nuorelle kohderyhmälle suunnatun Radio Mafian perustamiseen 1.6.199o. Reaktiivinen kanavauudistus tehtiin viisi vuotta sen jälkeen, kun paikallisradiot olivat aloittaneet lähetystoimintansa. (Kemppainen 2009: 123-124; Uimonen 2011.)

Paikallisradiot vauhdittivat suomirockin seitsemänkymmentäluvulta alkanutta nousukiitoa. 1980-luvulle tultaessa suomen kielellä tehty rockmusiikki myi paremmin, kuin kansainväliset artistit tai käännösversiot heidän kappaleistaan. Eppu Normaalin, Juice Leskisen, Popedan ja Dingon vanavedessä listoille nousivat rockin estetiikasta inspiroituneet iskelmäartistit, jotka edistivät suomalaista rockiskelmän syntyä ja menestystä. Musiikkiteollisuus eli nousukauttaan muun talouselämän tavoin, ja vaikka 1990-luvun alussa levyjen kappalemääräinen myynti laski taloudellisen taantuman ja vinyylilevyä hinnakkaamman cd:n vuoksi, kasvatti cd-tallenteiden korkeampi hinta Ääni- ja kuvatallennetuottajien (ÄKT ry) jäsenyritysten ja kauppiaiden markkamääräistä tuloa. (Bruun et al. 1998: 386; 469; Jalkanen \& Kurkela 2003: 602; Uimonen 2011: 50-51.)

Myös kotiäänittäminen lisääntyi voimakkaasti. 1970-luvun loppupuolella tehdyn vertailevan tutkimuksen mukaan 83 prosenttia suomalaisista käytti Yleisradion tarjontaa musiikkinauhoitustensa pääasiallisena lähteenä. (Teosto 1980: 18-19.) Tämän vahvistavat myös muistitietokeruun vastaukset, joiden mukaan kasetinkäyttäjistä 99 prosenttia koosti omat nauhansa. Valmiiksi nauhoitettuja 
kasetteja osti 75 prosenttia vastaajista. Musiikkia ja muuta tarjontaa tallennettiin ylivoimaisesti eniten radiosta (92\%), äänilevyiltä (78\%) ja kirjaston kokoelmista $(47 \%)$. Ns. treenikämppänauhoituksia teki neljännes kyselyyn osallistuneista; muita lähteitä olivat cd:t, televisio ja "kaverit", joilta haalittiin nauhoitettavaa kaikilta ajateltavissa olevilta formaateilta. (Kper 2010.)

Kasettia koskevissa tutkimuksissa on kasettisoitinten ja erityisesti korvalappustereoiden kohdalla korostettu, kuinka musiikkia kuunneltiin tilanteissa, joissa se oli ollut aiemmin mahdotonta. (Ks. Hosokawa 1984; Bull 2002.) Suomi ei poikkea yleisestä trendistä, sillä muistitietokeruun aineiston perusteella musiikkia kuunneltiin eniten kodin ulkopuolella korvalappustereoista (56\%), autosoittimista (40 \%) ja kannettavista kasettisoittimista (33\%). Kuitenkin vasta käyttäjien kertomuksista ilmenevät yksityiskohtaisesti ne eri tilanteet ja ympäristöt, joissa kasetteja käytettiin. Pitkähkö lista ansaitsee tulla esitellyksi tässä, sillä siitä käy erinomaisesti ilmi kuinka jokapaikkaista kasettimusiikin kuuntelu todellakin oli. Kasettimuistokeräykseen osallistuneet vastasivat "Missä kuuntelit kasettimusiikkia" -kysymykseen seuraavasti:

Kotona, autossa, töissä, työmatkoilla, opetuksessa, kaikkialla, mökillä, treenikämpällä, automatkoilla mummolaan, lomilla, sisällä ja ulkona, kavereiden luona, asuntovaunussa, rannalla, telttaretkillä, ulkoillessa, omassa huoneessa, vintillä, taksissa, tien päällä, bileissä, pyöräillessä, opiskelijakämpillä, linja-autossa, kasarmilla, lenkillä, hotellihuoneissa, kaikkialla, teltassa, laiturilla, puistoissa, Oriveden opistolla, missä tahansa, omassa huoneessa, kävellessä, junassa, tanssitunnilla, ongella, tikkaa heittäessä, riippumatossa, saunassa, metsässä, veneessä, siviilipalveluksessa, leireillä ja leirimatkoilla, joka paikassa kirkkoa lukuun ottamatta, i freestyle, koulumatkoilla, baarissa, uimarannalla, kesälomareissulla, kirjastossa, Inarin emäntäkoulussa, interraililla, heinäladossa, kellarissa, festivaaleilla, ruotsinsukulaisten Saabissa etupenkillä, kerhoissa, hyppytunneilla, välitunneilla, puutarhassa, jumpassa, nuorisotiloissa, dj-keikoilla, omassa punkassa, kadulla, töissä Turun taidemuseossa, på picknick, ute i skärgård, kotipihalla, leikkimökissä, kuntosalilla, kioskilla, nuorison kokoontumispaikoissa, luokkahuoneessa, kotibailuissa, isovanhemmilla, purjeveneessä, riparilla, partioleirillä, grillatessa, koiraa ulkoiluttaessa, tanssiharjoituksissa, veden alla uimahallissa, 
luokkaretkellä, koulun diskoissa, aamunavauksissa soitettiin virolaista punkia keskusradion kautta, tiskatessa, harrastuksissa, nukkumaan mennessä, huussissa, bänditreeneissä heti äänityksen jälkeen, lentokoneessa, läksyjä tehdessä, mummolassa, koripallokentällä, urheiluhalleilla, ekat kännit taisi mennä myös puistossa kasettimankan soidessa, leikkiessä, työhuoneella, rakentaessani taloa." (Kper 2010.)

Lukuiset käyttöyhteydet osoittavat kasetin ja kasettisoittimien erityislaadun, mutta samalla niiden arkiset ominaispiirteet verrattuna ensimmäisiin liikkuvan musiikin alustoihin ja toistolaitteisiin, gramofonilevyihin ja matkalaukkugramofoneihin. Vuoden 1929 gramofoninkäyttöä Helsingissä tarkastelevasta tutkimuksesta käy ilmi, kuinka laite muutti musiikin sosiaalista käyttöä ja kuinka gramofonimusiikista tuli osa juhlia, kyläilyjä, retkiä tai muita sosiaalisen yhdessäolon tilanteita (Männistö-Funk 2009). Kasettikin omaksuttiin pian osaksi juhlatilanteita ja monia muita sosiaalisen kanssakäymisen muotoja, mutta perusominaisuudeltaan ja käyttötavoiltaan se oli kuitenkin enemmän transistoriradiota muistuttava, gramofonilevyä proosallisempi laite. Se lisäsi musiikin käyttökonteksteja entisestään, mutta ennen muuta toi musiikin osaksi jokapäiväistä elämää, arkea ja työtä.

Kasettia oli mahdollista käyttää "kaikkialla" ja "joka paikassa". Arjen äänimaiseman muuttumisen kannalta ratkaisevaa oli sekin, että siinä missä gramofonin myötä musiikki lähti liikkeelle, kasetin tekniset ratkaisut tekivät mahdolliseksi kuunnella haluamaansa musiikkia myös liikkumisen yhteydessä: työmatkoilla, lenkillä, autossa ja niin edelleen. Musiikki kulki käyttäjänsä mukana kaksikymmentäneljä tuntia vuorokaudessa tauotta tämän niin halutessa.

Yksityiskohtaisemmat muistelut tuovat varmuudella lisää tietoa kasetin käyttötilanteista. Tästä olkoon esimerkkinä vuonna 1985 syntyneen miehen kommentti siitä, kuinka "ensimmäinen kasetti, jonka muistan oli Raptorin Moe! Kaveri toi sen tarhaan ja sitä kuunneltiin jatkuvalla toistolla hoitajien iloksi" (Kper 2010: Km/362). Muistelijan kohdalla kasettiin ja ajan populaarimusiikkiin tutustuminen tapahtui varsin varhaisella iällä. Seuraavassa tarkastelen sitä, minkä ikäisenä ja kuinka kasetin käyttö opittiin sekä mitkä tekijät oppimiseen vaikuttivat. 


\section{Kasetinkäyttäjäsukupolvet}

Vaikka kasetti vaikutti merkittävällä tavalla suomalaisten musiikinkuunteluun, ei uusi teknologia ja sen käyttöönotto ollut se vastustamaton voima, joka yhtäkkiä muutti musiikinkuuntelijoiden päivittäisrutiinit toisiksi. Muutoksessa on kyse käyttäjän ja teknologian vuorovaikutuksesta, jota voidaan tarkastella kotouttamisen käsitteen avulla. Tästä näkökulmasta teknologia ei vain ja ainoastaan asetu osaksi arkea puhumattakaan, että kyse olisi yksittäisestä tapahtumasta, vaan pidempiaikaisesta prosessista. Laitteita ei myöskään oteta käyttöön sellaisenaan, vaan niiden käyttötavat määrittyvät ja muotoutuvat ajan myötä. (Haddon 2003: 45-45; Peteri 2006: 55.) Kasetin vaikutukset käyttäjiensä musiikinkulutukseen riippuivat myös siitä, missä ikävaiheessa nämä oppivat käyttämään uutta formaattia. Vastattavaksi myös jää, kuinka eri-ikäiset käyttäjät omaksuvat uuden teknologian ja mitä he sillä tekevät.

Aihetta voidaan tarkastella sukupolven käsitteen avulla. Sosiologi Matti Alestalo tukeutuu Karl Mannheimiin (1893-1947) ja kirjoittaa, kuinka ranskalaiseen valistusajatteluun perustuvan positivistisen lähestymistavan mukaan sukupolvet ovat kvantitatiivisiä ilmiöitä: ne seuraavat toinen toistaan tasaisin väliajoin. Romanttis-historiallisen tarkastelukulman taustalla vaikuttaa puolestaan saksalainen historiallinen ajattelu, jonka perusteella historiankulkua ei käsitetä lineaariseksi. Lisäksi eri sukupolvet vaikuttavat historiaan eri tavoin. Mannheimin mukaan sukupolvien määrittelyssä merkittäviä ovat nuoruuden kokemukset. Samaan sukupolveen kuuluvia yhdistävät kokemukset, ajatukset ja käsitteet, joskin asuinpaikasta riippuen ne saattavat poiketa toisistaan huomattavastikin. (Mannheim 1952; Alestalo 2007: 146.)

Äänittäjien käyttäjien asuinpaikalla asuinpaikalla oli ratkaiseva merkitys materiaalisessakin mielessä. Esimerkiksi helsinkiläisen tai virtolaisen kotiäänittäjän mahdollisuudet hankkia musiikkia käyttöönsä erosivat huomattavasti toisistaan. Pääkaupunkiseudulla vuoden 1985 jälkeen toimintansa aloittaneet kaupalliset radiot monipuolistivat alueen musiikkitarjontaa suuntaamalla ohjelmatarjontansa erityyppisille radionkuuntelijoille. (Uimonen 2005.) Lisäksi musiikkia oli mahdollista hankkia lukuisista äänilevyihin erikoistuneista liikkeistä. Virtolaisen kotiäänittäjän musiikin lähteinä oli Yleisradion musiikkitarjonta, telinemyynti, postimyynti ja läheisen Tampereen äänilevyliikkeiden tarjonta. (Lounela 1995.) 
Sukupolven muodostuminen edellyttää, että siihen kuuluvat ovat syntyneet keskimäärin samaan aikaan ja että heillä on yhteisiä elämänkokemuksia sekä niille perustuvia yhteisiä muistoja. (Alestalo 2007: 148, 153.) Näitä ovat esimerkiksi musiikilliset avainkokemukset, joita on tutkittu rytmimusiikin soittajien ja musiikinvalinnasta vastaavien radiotoimittajien kohdalla. (Kurkela 2005; Lahti 2007.)

Voidaanko edellisen perusteella puhua kasettisukupolvista ja arvioida sitä, kuinka kasettimusiikista tuli osa suomalaisten musiikinkuuntelua? Kasetin käytön omaksumista tutkittaessa hyvinkin: henkilökohtaiset muistot kasetin käytöstä ovat joissakin tapauksissa eri ikäryhmille yhteisiä, mutta toisaalta myös erottavat heidät toisistaan (ks. kuitenkin Kilpiö \& Uimonen 2010). Vaikka kasetin helppokäyttöisyys ja kotiäänittäminen yhdisti eri sukupolvia, eivät ne vielä kerro kasetin käytön oppimisesta tai siitä, kuinka varhain kasetinkäyttö omaksuttiin ja millä tavalla uuden välineen omaksumisprosessi erosi edeltävien sukupolvien vastaavasta. Muistitietoaineiston perusteella miltei joka toinen vastaaja mainitsee oppineensa kasetinkäytön kotona, mikä onkin ymmärrettävää, sillä etenkin 1970-luvulla taskurahat, kasettinauhuriin sijoitettavista rahoista puhumattakaan, olivat nuorilla vähäisiä (Kilpiö \& Lehtinen 2011: 28).

Internet-vastaajien ikäjakauma

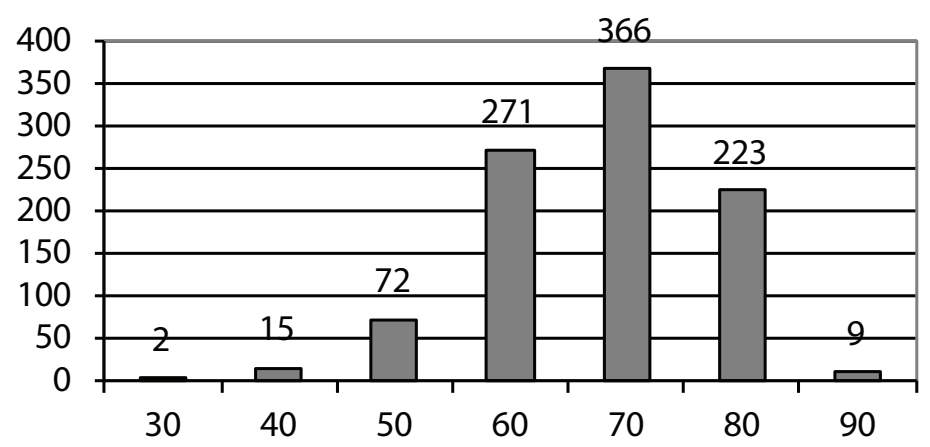

Kasetin käytön aloittamista voidaan tarkastella keräämämme muistitietokeruuaineiston avulla. Kaikille vastaajille avoin kysely järjestettiin vuonna 2010 Musiquitous-projektin ja Suomalaisen Kirjallisuuden Seuran yhteistyönä seuran vastaajaverkoston avulla ja internetissä. Internet-kyselyyn vastasi 958 kasetinkäyttäjää. 
Kasetinkäyttäjät olivat syntyneet vuosina 1930-1990, heistä miesvastaajia oli 53 prosenttia ja naisia 47 prosenttia. Kasettia käyttivät eniten 1960-1980-luvuilla syntyneet, joita oli lähes 90 prosenttia vastaajista. Onkin varsin luontevaa tarkastella kuinka näiden kolmen vuosikymmenen aikana syntyneet sukupolvet oppivat käyttämään kasettia ja mihin he taitojaan käyttivät.

Jako kolmeen sukupolveen ja vuosikymmeneen palvelee aineiston analyysia. On selvää, etteivät erot kasetin käytössä jakaannu näin yksiselitteisesti: useasti 1970-luvun lopulla syntyneiden kokemukset olivat enemmän yhteneviä 1980-luvun alkupuolella syntyneiden kuin 1970-luvun alussa syntyneiden kanssa. Lisäksi uusien kuunteluvälineiden ja formaattien, kuten korvalappustereoiden tai cd:n yleistyminen muutti musiikin kuuntelua kaikkiin sukupolviin kuuluvien henkilöiden kohdalla - jos ylipäänsä oli muuttaakseen. Olen nimennyt kasetinkäyttäjät radionauhuri-, satukasetti- ja korvalappustereosukupolviksi sen perusteella, millä laitteella kasetinkäyttö yleisimmin aloitettiin ja mitkä laitteet erottivat uuden sukupolven sitä edeltävästä.

\section{Radionauhurisukupolvi}

Radionauhurisukupolven (s. 1960-1969) ensimmäinen laite oli kasettisoitin tai radiokasettinauhuri. Laite hankittiin lapsuuden kotiin tai ostettiin itse, kun se tuli taloudellisesti mahdolliseksi. Sukupolvi omaksui kasetinkäytön pääsääntöisesti 1970-luvulla ja kymmenkesäisenä, joskin vuosikymmenen loppupuolella syntyneissä oli mukana jo ennen kouluikää kasettiin tutustuneita lapsia. Nauhureita ja kasetteja saatiin joulu- ja syntymäpäivälahjoiksi sekä voitettiin palkintoina erilaisista kilpailuista.

Muistitietokyselyn mukaan kasettisoitin hankittiin "meille" ts. vanhemmat ostivat laitteen koko perheen käyttöön. Yleistä oli myös, että myöhemmin perheen nuorille ostettiin oma soitin. Usein nauhurin käyttö opittiin muilta perheenjäseniltä tai opeteltiin itse. Kasetti kotoutettiin osaksi perheen arkea lukuisin eri tavoin. Erään muistelijan mukaan kasettisoittimen oston yhteydessä perheenjäsenille hankittiin omat kasetit nauhoituksia varten. Musiikin tallennuksen ja kuuntelun ohella kasetin perhekäyttöä oli muun muassa äänikirjeiden laatiminen isovanhemmille. Vuonna 1965 syntynyt nainen muistelee, kuinka radiokasettisoitin tuli osaksi perheen musiikinkuuntelua ja kotiäänittämistä: 
"Kotiini hankittiin ensimmäinen radiokasettinauhuri (Philips) joskus 1970-luvun alussa. Se oli vain äidin käytössä. Äitikin äänitti itse musiikkia radiosta, mutta meillä oli myös joitakin valmiiksi nauhoitettuja kasetteja, ainakin muistan Marion Rungin setin, jolla oli mm. Abba-covereita". (Kper 2010: Km/720.)

Perheessä uutta radiokasettinauhuria käytti ensin aikuinen, vaikka todennäköisesti tallennus ja toisto olisivat onnistuneet helppokäyttöisellä laitteella tuolloin hieman alle kymmenvuotiaalta kasetinkäyttäjältäkin. Vanhemman esimerkkiä seuraamalla opittiin äänittäminen, minkä jälkeen sisarukset tallensivat musiikkia aktiivisesti eri lähteistä, kuten radiosta, televisiosta ja kaveripiiriltä:

\footnotetext{
"Siskon kanssa saimme oman yhteisen nauhurin n. 1975-77, en muista tarkkaan.

Nauhoitimme kumpikin omaa suosikkimusiikkiamme, jota tosin tuli harvoin.

Huippukaappaus oli saada kasetille Baccaraa tai Armin ja Dannyn kappaleita.

Äänitimme myös mankan sisäänrakennetun mikrofonin kautta televisiosta mu-

siikkia kasetille. Taso oli huippua! Muistan myös yläasteaikanani ostaneeni kaverilta itse nauhoitetun c-kasetin, jolla oli Boney M:n uutuuslevy, se oli nauhoitettu radio Luxemburgista. [...]". (Kper 2010: Km/720.)
}

Ajalle tyypillisesti suosikkimusiikkia oli tarjolla vähän, minkä vuoksi kotiäänittämisen tähtihetket olivat jääneet tallentajan mieleen "huippukaappauksina". Äänenlaatu ei ollut ratkaiseva tekijä, mistä muistelija televisionauhoitusten yhteydessä hieman lakonisesti huomauttaakin. Mainosrahoitteisen Radio Luxembourgin lähetykset kantoivat muun Euroopan ohella Suomeen ja lisäsivät populaarimusiikin kuuntelun mahdollisuuksia sekä tekivät mahdolliseksi pienimuotoisen kaupankäynnin ja taskurahojen hankkimisen.

Muistelijat hankkivat kasettisoittimia ja kasetteja omaan käyttöönsä kesä- tai muilla tienesteillä. Taloudelliset edellytykset tähän olivat 1970-luvulla verrattain hyvät, ainakin kun niitä vertaa ensimmäisen mobiilimusiikkilaitteen ostajien mahdollisuuksiin 1920-luvun lopulla. Tuolloin matkagramofoni maksoi kaksikymmentä prosenttia enemmän, kuin mikä oli helsinkiläisen konttoriapulaisen tai sekatyömiehen kuukausiansio, joskin edullisempiakin malleja oli tarjolla. (Männistö-Funk 2009.) Kasettinauhuriakaan ei saanut omakseen pikkurahalla, mutta kuitenkin huomattavasti alle konttoriapulaisen tai työmiehen kuukausian- 
sioiden: vuonna 1974 Suosikki-nuortenlehden lukijakilpailun palkintona olleen Philips radiokasettinauhurin hinnaksi ilmoitettiin 700 mk (637 e), Sankyon sai noin sata markkaa halvemmalla (S 1974b: 25; 76; TK 2012).

\section{Satukasettisukupolvi}

Satukasettisukupolven (s. 1970-79) ensimmäinen kohtaaminen kasetin kanssa tapahtui usein siitä tietämättä. Kasettimuisteluista käy ilmi, kuinka heidän vanhempansa olivat dokumentoineet lastensa leikkejä tai vauvan ääntelyä (ks. myös Järviluoma, Koivumäki, Kytö \& Uimonen 2006: 218). Oman kasetinkäyttönsä sukupolvi aloitti viimeistään 1980-luvulla, jolloin kasetti oli jo saanut vankan jalansijan osana suomalaisten arkea. Tässä vaiheessa voidaan hyvällä syyllä puhua varhaisesta musiikin jokapaikkaisuudesta, sillä 1970-luvun alussa syntyneet kertovat vastauksissa, kuinka kasetteja oli "aina".

Usein nauhurinkäyttö opittiin jo ennen lukutaitoa. Satukasettien sisältö muistettiin yksityiskohtaisesti, myös se, millaisen äänimerkin jälkeen kasetti tuli kääntää toisin päin. Vuonna 1979 syntyneen naisen äänimuistossa signaali yhdistyi kotona äänitettyyn satutuokioon: "Oltiin todella pieniä kun äiti luki satukirjoja kasetille ja sanoi aina 'piip' kun piti kääntää sivua" (Kper 2010: Km/625).

Tämäkin sukupolvi oppi kasetinkäytön muilta perheenjäseniltä. Kasetin sosiaaliset ja tekniset käytöt olivat kuitenkin monipuolistuneet: sukupolven ensikosketus kasettinauhan tarjoamiin mahdollisuuksiin saattoi olla isoäidin lähettämä äänikirje jouluna, toiset taas tutustuivat nauhaan Commodore 64-tietokoneen käytön yhteydessä, kunnes myöhemmin havahtuivat siihen, että kasetti käy myös musiikin tallentamiseen. (Km 2010.)

Etenkin kasetinkäytön alkuvaiheessa kuuntelua tärkeämpää toimintaa olivat useasti omat nauhoituskokeilut: laulut, puheet tai "radio-ohjelmien" laatiminen. Tämä ilmenee vuonna 1973 syntyneen miehen kertomuksesta.

\footnotetext{
"Lapsena kasetit sisälsivät pääosin omia äänityksiäni: selostuksia, ääneen luettuja sarjakuvia, omia kuunnelmia ja tv:n kaiuttimesta äänitettyjä lastenohjelmia (1978-1983). Nuorena äänitin levyiltä rokkia Kissistä Hanoi Rocksiin sekä tietysti treenikämpältä oman bändini soittoa. Sittemmin äänittelin kaseteille aina
} 
lähinnä uutuuslevyjä, joita kuunneltiin mankasta ulkona. 1980-luvun loppupuolella kuuntelin etupäässä hardrockia ja heviä, esimerkkiyhtyeinä vaikkapa Van Halen, Ac/DC, Helloween ja Metallica. Ehdin 18-vuotiaana tehdä vain muutaman "autokokoelman", kun cd-soitin korvasi kasetit automatkoilla (1984-1991)." (Kper 2010: Km/358.)

Kasetin tallennusominaisuudet taipuivat hyvin käyttäjänsä musiikkimaun ja käyttötarpeiden muutoksiin. Lapsuuden leikkivälineellä tallennettiin omaa ääntä ja julkisrahoitteisen Yleisradion tarjontaa, mitä seurasi ajan suosikkiartistien nauhoittaminen ja nauhojen kuljettaminen kodin ulkopuolelle sekä oman musisoinnin dokumentointi. Autokasetit lisäsivät musiikin liikkuvuutta entisestään, kunnes cd-levyt korvasivat ne kolmetoista vuotta kasetinkuuntelun aloittamisen jälkeen.

Kasetinkäytön varhaisen oppimisen teki mahdolliseksi kasetin ja nauhureiden kestävyys ja helppokäyttöisyys. Vaivattoman formaatin tallennusominaisuuksiin oltiin ehditty totutella jo hyvissä ajoin, ennen kuin heräsi tarve käyttää sitä musiikin tallentamiseen ja kuunteluun. Tämän huomasivat myös laitevalmistajat, jotka ryhtyivät suuntamaan tuotteitaan lapsille ja varhaisnuorille. Tunnetuin lienee Sony Corporationin vuonna 1987 esittelemä kasettisoitin My First Sony. Yhtiön markkinointistrategiana oli luoda brändiuskollisuutta niin, että kuluttajat ryhtyisivät Sonyn tuoteperheen käyttäjiksi jo varsin nuorella iällä (du Gay 1997: 133).

1970-luvulla yleistynyt kasetti oli viimeistään 1980-luvulla kotoutettu yhtä tiiviimmin koko perheen mediaksi, eräänlaiseksi valokuva- tai perhealbumin äänelliseksi vastineeksi, johon perheen tapahtumia tallennettiin. Vähittäismyyjille suunnatuissa mainoksissa kasetinkäyttöä argumentoitiin rationaalisin perustein: kuinka se soveltuu muistiinpanovälineeksi työn ja koulunkäynnin yhteydessä. (Kilpiö \& Uimonen 2010.) Työelämän järkevän välineellisyyden rinnalle tuli kuitenkin päivittäisen elämän ja arjen tallentaminen, jonka dokumentointi koettiin arvokkaaksi itsessään. Itse dokumentointitapahtuman merkitystä korostaa se, että maininnat nauhoitustapahtumista olivat huomattavasti lukuisampia, kuin muistot siitä, että perhe-elämää tallentaneita kasetteja olisi tosiasiallisesti kuunneltu. 
Syynä tähän oli äänen vaatima huomio. Kasettinauhan kuuntelusta poiketen valokuvien selaaminen ja niistä keskusteleminen oli varsin vaivatonta sosiaalisen kanssakäymisen yhteydessä. Nauhan soittaminen ja äänimuistojen mieleen palauttaminen edellytti läsnäolijoilta keskittynyttä kuuntelua ja keskustelun lopettamista. Äänelliseksi valokuva-albumiksi kasetista ei ollut, kuten ei ollut sitä edeltäneestä kelanauhuristakaan, jota myös markkinoitiin tähän nimenomaiseen tarkoitukseen. (vrt. Bijsterveld \& Jacobs 2009: 41.)

\section{Korvalappustereosukupolvi}

Korvalappustereosukupolvi (s.1980-89) omaksui edellisen sukupolven tavoin kasettinauhurin ensiksi leikkivälineeksi: sillä tallennettiin ja toistettiin puhetta ja musiikkia, usein vanhempien kokoelmista. Liikkuva musiikinkuuntelu alkoi edeltäviä sukupolvia aiemmin, mikä johtui korvalappustereoiden yleistymisestä 1980-luvun puolivälissä. Laitteita saatiin lahjaksi alle kouluikäisinä.

Edellisen sukupolven tavoin korvalappustereosukupolvi tutustui aluksi satukasetteihin. Niillä oli selkeästi sama käyttötarkoitus perheen ollessa matkoilla, kuin videonauhalla ja kotioloissa: lasten ja aikuisten viihtyvyyden lisääminen. Tämä ilmeni myös huoltoasemien kasettitarjonnassa. Vaikka kattava kartoitus huoltoasemien telinemyynneistä on toistaiseksi tekemättä, kuului ainakin keväällä 1993 virtolaisen тв-huolto O. Koskisen valikoimaan Finn-Jusa -tukkumyynnin välittämiä kasetteja, jotka olivat lähinnä "matka- ja lastenmusiikkia" (Lounela 1995: 104).

Matkalla kuunnellut kasetit sisälsivät varsin monentyyppistä musiikkia. Vuonna 1987 syntyneen naisen muistelussa valmiiksi äänitetyistä kaseteista "kolme on ylitse muiden" joista yhtenä "kaamea lasten joululaulukasetti, jota pikkusiskoni, syntynyt vuonna 1990, tahtoi jostakin kumman syystä aina kesäisillä mummolamatkoilla kuunnella". (Kper 2010: Km/385.)

Korvalappustereosukupolven kasetinkäytön omaksumiseen vaikuttivat sukulaiset ja leikkikaverit. Vaikutukset ulottuivat myös musiikin sisältöön, sillä lastenmusiikin ja satukasettien rinnalla kuunneltiin ajan hittiartisteja. Vuonna 1980 syntynyt mies kertoo olleensa neljän vanha, kun sai "isoveljeltä nauhoitetun c-kasetin, jossa oli wAspia". Vuonna 1988 syntynyt mies puolestaan muistelee, 
kuinka "joskus tarha-aikoihin faija pystytti mun ja veljen huoneeseen stereot ja löi käteen Bad Religion CD-levyn ja Ac/Dc livekasetin" (Kper 2010: Km/ 443; 307).

Populaarimusiikki oli tullut osaksi kuuntelijoiden arkipäivää entistä varhaisemmassa elämänvaiheessa. Satukasettien jälkeen siirryttiin kuuntelemaan heavy-rockia ja rap-musiikkia, mihin vaikuttivat vanhempien ja sisarusten antama esimerkki. Musiikilliset avainkokemukset viitoittivat tietä myöhemmälle, valikoivammalle musiikinkuuntelulle. Vuonna 1983 syntyneen miehen kertomuksessa yhdistyvät lastenkasetit, saman vuosikymmenen aikana tapahtunut äänimaiseman rokittuminen, oman musiikkimaun löytyminen, kotiäänittäminen ja viimein itse äänitetyistä kaseteista luopuminen.

\footnotetext{
"Ensimmäisenä Rölli-kasetit. Sitten vanhemmilta saatu Karavaanari-kasetti, joka sisälsi yhden hyvän kappaleen: Kirkan versio Born to be Wildistä. Tämän jälkeen rockia, hard rockia ja heavyä. Nykyään olen hankkiutunut eroon nauhoitetuista kaseteista ja hyllystäni löytyy vain aidot kasetit." (Kper 2010: Km/84.)
}

Kun 196o-luvulla syntyneet aloittivat kasettikuuntelun pääsääntöisesti kymmenvuotiaana tai kesähankkeilla ostetuilla laitteilla, oli osa 1980-luvulla syntyneestä korvalappustereosukupolvesta tuohon ikään mennessä ehtinyt vaihtaa kasettiformaatin cd-levyihin. Vuonna 1989 syntyneen vastaajan kasetinkäyttö jäikin perin lyhytaikaiseksi: se alkoi satukasettien kuunteluna ja loppui kymmenkesäisenä, kun hän sai tietokoneen ja polttavan cd-aseman (Kper 2010: Km/81).

\section{Johtopäätökset}

Kasettikulttuuri on erottamaton osa musiikkitarjonnan ja musiikinkulutuksen muutosta Suomessa. Tähän liittyen olen artikkelissani tarkastellut sitä, millä tavoin kasetin käytön omaksuminen muutti eri kasettisukupolvien musiikinkuuntelukäytäntöjä. Äänen tallentamisen ja toistamisen historialliseen kontekstiin asetettuna kyse on varhaisesta ubiikkiudesta, musiikin jokapaikkaistumisesta: c-kasetti jatkoi ja uudisti matkagramofonin, transistoriradion ja kelanauhan aloittamia käytäntöjä, jotka mahdollistivat mobiilin musiikinkuuntelun. 
Musiikin kuuntelu ja käyttötavat tuottavat osaltaan musiikkityylejä ja repertuaareja sekä vaikuttavat oleellisesti niiden muodostumiseen. Kasetin kohdalla tämä ilmenee itsestään selvästi kotiäänittämisessä. Itse tehtyjen kokoelmanauhojen myötä kyettiin koostamaan nauhoituksia tietylle henkilölle tai henkilöille sekä personoimaan nauhan sisältö, kasetin kuoret ja kasettikotelon kansi tähän tarkoitukseen sopivaksi. "Poppareiden lelusta" tuli merkittävä väline, kun kasettimusiikilla rakennettiin uusia sosiaalisuuden ja yksityisyyden muotoja sekä arjen äänimaisemaa. Uuden formaatin saatavuus ja arkipäiväistyminen muuttivat entisestään käsitystä siitä, että musiikki olisi sidottu ainoastaan tiettyihin tapahtumiin ja kuuntelutilanteisiin. Transfonisesta laulusta ja soitosta tuli päivittäinen seuralainen työssä ja vapaa-ajalla varsin pian, minkä vahvistaa muistitietoaineistossa esiintyvien kasetin käyttökontekstien runsaus ja monipuolisuus.

Kasetinkäytön vaivattomuus edesauttoi formaatin kotouttamista osaksi perheiden jokapäiväistä musiikinkuuntelua. Musiikkia tallentamaan ja toistamaan kykenivät käytännöllisesti katsoen kaikki riippumatta iästä tai teknisestä orientaatiosta. Osa ubiikkia musiikinkuuntelua oli myös se, kuinka musiikin käyttäjät suhtautuvat musiikkia välittävään formaattiin ja kuinka siitä kertoivat. Laitteesta on tullut osa jokapäiväistä elämää silloin kun käyttöön ei enää kiinnitetty erityistä huomiota.

Eri sukupolvien kohdalla kasetinkäyttötavat muuttuivat 1970-luvulta 1990-luvulle siirryttäessä. Kulta-aikana voidaan kuitenkin pitää 1980-lukua, jolloin kasettien myynti oli huipussaan. Samaan aikaan yleistyivät korvalappustereot ja kaksipesäiset nauhurit, jotka lisäsivät entisestään kasetin käyttöyhteyksiä. Yhteiskunnan rokittuminen kuului myös kasetin käytössä: lasten ja nuorten musiikki muuttui "aikuisemmaksi" ehkä varhaisemmassa vaiheessa kuin tätä ennen, kun vanhemmat alkoivat muokata jälkikasvunsa musiikillista maailmankuvaa haluamaansa suuntaan ja tarjota näille hyviksi havaitsemiaan vaihtoehtoja.

Edellä kerrotun perusteella voidaan hahmotella uusia tutkimuskysymyksiä ja etsiä niihin vastauksia muistitietoaineistosta. Vastattavaksi tulee muiden muassa se, mikä oli kasetin ja kasettimusiikin suhde muuhun mediatarjontaan ja mitä musiikkia kaseteilta kuunneltiin. Alustavan tarkastelun perusteella etenkin kotiäänittäminen laajensi jo olemassa olevia musiikinkulutuksen tapoja. Konserttikäynnit, levyjen ostaminen, kirjaston musiikkikokoelmien hyödyntäminen ja kokoelmakasettien äänittäminen olivat kiinteästi toisiinsa kytköksissä olevaa, 
musiikin monimediaalista käyttöä. Kotiäänittäminen teki musiikinkuluttamisesta määrällisesti ja laadullisesti rikkaampaa: ei ainoastaan yhden formaatin määrittelemissä rajoissa, vaan myös suhteessa muihin tapoihin kuluttaa niin medioitunutta kuin elävääkin musiikkia.

\section{Lähteet}

Ak (1979) Kirka. 1970-luku kokoelmat, <http:/ / www.kirka.com/index.php?option=com_content\& task $=$ category \&sectionid $=6 \&$ id $=22 \& I$ temid $=96 \&$ limit $=25>($ luettu 17.3.2012 $)$.

Alestalo, Matti (2007) "Rakennemuutokset ja sukupolvet". Yhteiskuntapolitiikka 72: 2, ss. 146-157.

Bijsterveld, Karin \& Jacobs, Annelies (2009) "Storing Sound Souvenirs: The Multi-Sited Domestication of the Tape Recorder". Sound Souvenirs. Audio Technologies, Memory and Cultural Practices. Toim. Karin Bijsterveld \& José van Dijck. Amsterdam: Amsterdam University Press. Ss. 25-42.

Bruun, Seppo, Lindfors, Jukka, Luoto, Santtu \& Salo, Markku (1998). Jee, jee, jee: suomalaisen rockin historia. Helsinki: wsoy.

Bull Michael (2002) "The Seduction of Sound in Consumer Culture. Investigating Walkman desires". Journal of Consumer Culture Vol. 2 (1), ss. 81-101.

du Gay, Paul; Hall, Stuart; Janes, Linda; Mackay, Hugh \& Negus, Keith (1997) Doing Cultural Studies. The Story of Sony Walkman. Glasgow: Sage.

Frith, Simon (1986) "Art versus technology: the strange case of popular music". Media, Culture and Society, ss. 263-279.

Gronow, Pekka \& Saunio, Ilpo (1990) Ä̈̈nilevyn historia. Porvoo: wsoy.

Haddon, Leslie (2003) "Domestication and Mobile Telephony". Machines that Become Us. The Social Context of Personal Communication Technology. Toim. J.E. Katz. New Brunswick: Transaction Publishers. Ss. 43-56.

Hancox, Dan (2010) "Mobile disco. How phones make music inescapable". Guardian, <http:/ / www.guardian.co.uk/music/2010/aug/12/sodcasting-music-in-public-mobilephones> (luettu 17.3. 2012). 
Heikkilä, Henna (2007) Jokapaikan tietotekniikan käytettäoyys. Pro gradu -tutkielma.

Tietojenkäsittelytieteiden laitos. Tampereen yliopisto.

Hosokawa, Shuhei (1984) "The Walkman Effect". Popular Music, vol. 4, Performers and Audiences, ss. 165-180.

Jalkanen, Pekka \& Kurkela, Vesa (2003) Populaarimusiikki. Suomen musiikin historia. Helsinki: WSOY.

Joukkoviestimet (1998) Joukkoviestimet. Helsinki: Tilastokeskus.

Järviluoma, Helmi; Koivumäki, Ari; Kytö Meri \& Uimonen, Heikki (2006) Sata suomalaista äänimaisemaa. sKs: Helsinki.

Kassabian, Anahid (2002) "Ubiquitous Listening". Popular Music Studies. Toim. David Hesmondhalgh \& Keith Negus. Oxford: Oxford and New York. Ss. 131-142.

Katz, Mark (2004) Capturing Sound. How Technology has Changed Music. University of California Press: London.

Kemppainen, Pentti (2009) "Reporadiosta Rockradioon". Musiikki tekee murron. Tutkimuksia sävel- ja hittiradioista. Toim. Vesa Kurkela. Tampereen yliopisto musiikintutkimuksen laitos: Tampere. Ss. 85-142.

Kemppainen, Pentti (2011) Radiomusiikista musiikkiradioon. Helsinki: Avain.

Kilpiö, Kaarina \& Uimonen, Heikki (2010) "Kulkee mukana eikä maksa paljon. Kuinka c-kasetti muutti äänimaisemaa". Historiallinen aikakauskirja 3/2010, ss. 329-341.

Kilpiö, Kaarina \& Lehtinen, Vilma (2011) "Bulkista uniikiksi - merkitystä massatuotettuihin musiikkisisältöihin". Media ja viestintä 4/2011 ss. 26-47.

Kper (2010) Kasettimuistot. Musiquitous-tutkimushankkeen ja Suomalaisen Kirjallisuuden Seuran muistitietokeruu huhti-syyskuussa. Kansanperinteen arkisto, Tampereen yliopisto.

Lahti, Maija (2007) "Radiomusiikin portinvartijat ja musiikkisukupolvet. Tapaustutkimus Radio Paitapiiskan musiikkivalintaprosesseista". Etnomusikologian vuosikirja 19. Toim. Markus Mantere \& Heikki Uimonen. Helsinki: Suomen Etnomusikologinen Seura. Ss. 29-51.

Kurkela, Vesa (2005) "Tanssisoiton tuntematonta historiaa". Soittaja pärjää aina - eteläpohjalaiset muusikot muistelevat. Toim. Vesa Kurkela \& Terho Kemppi. Tampere: Pilot-kustannus. Ss. 7-18.

Lounela, Kari (1995) "Mistä Virpi Virtolainen ostaa äänitteensä". Musiikkimaailmoja ja äänimaisemia. Virtain kuulokulma. Toim. Helmi Järviluoma. Tampere: Kansanperinteen laitos. Ss. 101-109.

Mannheim, Karl (1952) Essay on Sociology of Knowledge. Toim. Paul Kecskemeti. London: Routledge \& Kegan Paul. 
Manuel, Peter (1988) Popular Musics of the Non-Western World. An Introductory Survey. Oxford University Press: Oxford.

Manuel, Peter (1993) Popular Music and Technology in North India. Chicago: University of Chicago Press.

Muikku, Jari (2001) Musiikkia kaikkiruokaisille. Suomalaisen populaarimusiikin äänitetuotanto 19451990. Helsinki: Gaudeamus.

Musiq (2012) Musiquitous, <http://musiq.fi/> (luettu 17.3.2012).

Männistö-Funk, Tiina (2009) "Säveltulva kaupungissa - Gramofonimusiikki uudenlaisena kaupungin äänenä ja makukysymyksenä Helsingissä 1929". Ennen ja nyt. Historian tietosanomat, <http:/ /www.ennenjanyt.net/?p=272\#ffootnote_44_272> (luettu 17.3.2012).

Peteri, Virve (2006) Mediaksi kotiin. Tutkimus teknologioiden kotouttamisesta. Tampere: Tampere University Press.

Stockfelt, Ola (1997) “Adequate Modes of Listening". Keeping Score: Music, Disciplinarity, Culture. Toim. David Schwartz, Anahid Kassabian \& Lawrence Siegel. Charlottesville and London, University Press of Virginia. Ss. 129-146.

S (1971) Suosikki. Marraskuu. Tekniikan maailma -lehden mainos “Vertailimme kasettinauhureita".

S (1974a) Suosikki. Marraskuu.

S (1974b) Suosikki. Syyskuu.

Teosto (1980) Gallup survey concerning the music recording habits in Finland, Sweden, Norway and Denmark. Teosto, NCB, Nordic Groups of IFPI.

тK (2012) Tilastokeskus. Rahanarvonkerroin 1860-2011, <http:/ / www.stat.fi//til/khi/2011/ khi_2011_2012-01-18_tau_001.html> (luettu 18.9.2012).

Uimonen, Heikki (2005) Ä̈̈ntä kohti. Ä̈̈niympäristön kuuntelu, muutos ja merkitys. Tampere: Tampere University Press.

Uimonen, Heikki (2011) Radiomusiikin rakennemuutos. Kaupallisten radioiden musiikki 1985-2005. Tampere: Tampere University Press.

Wallis, Roger \& Malm, Krister (1984) Big sounds from small peoples. The music industry in small countries. London: Constable. 